\title{
Verset en rewolusie
}

I W C van Wyk

Tydelike dosent: Departement Dogmatiek

en Christelike Etiek (Afd A)

Universiteit van Pretoria

\begin{abstract}
Resistance and revolution.

The communion formulary of the Nederduitsch Hervormde Kerk states clearly that a church member may not take part in revolutionary activities and that he should obey governmental authorities. Two questions are asked: 1. Does this statement imply that a Christian should obey goverments, even when they are oppressive? Can a Christian do something about his fate, or is he obliged to suffer injustice? 2. How can and must we interpret this principle today in a democratic state where resistance and rebellion are integral elements of the political process? It is argued that in Biblical-Reformed theology not only the duty to obey but also the right to resist are justified. Although civil disobedience is allowed, violence is strongly condemned. This article asks the church to adhere to the communion formulary, but simultaniously to realise the vast differences between the sixteenth and the twentieth centuries.
\end{abstract}

\section{INLEIDING}

Die 63ste Algemene Kerkvergadering van die Nederduitsch Hervormde Kerk van Afrika het 'n hele reeks besluite oor protes en protesoptogte geneem (kyk NHKA 1992:48-50). Hierdie besluite was geneem op grond van my studiestuk vir die Raad vir Maatskaplike Sake, getitel 'Protesoptogte en die rol van die Nederduitsch Hervormde Kerk' (gepubliseer in die HTS 47, 716-745). In hierdie studiestuk is protes en weerstand as beginsels aanvaar wat nie noodwendig met die Christelike etiek in stryd is nie. Trouens, dit is as wesenlike elemente van 'n demokratiese regstaat beskryf. Hierdie studiestuk neem die argument verder. Hier word gevra: mag gelowiges hulle teen onreg verset en mag hulle aan 'n rewolusie teen 'n onderdrukkende owerheid deelneem? Wanneer is gewelddadige opstand geregverdig, indien ooit? Watter omstandighede verhinder gewelddadige opstand? Wat behoort die kerk se optrede teenoor opstandelinge te wees? Die kerk moet vandag weer oor hierdie sake standpunt inneem. Hiervoor bestaan daar minstens twee goeie redes: 
* Volgens die nagmaalsformulier mag die nagmaal nie aan lidmate bedien word wat rewolusie teen die staat wil veroorsaak of hulle wat die owerhede misken nie. Ons het dus hier met 'n saak te make wat die kerklike tug ten diepste raak.

* Rondom die algemene verkiesing van April 1994 in Suid-Afrika was daar lidmate en ampsraers van die Nederduitsch Hervormde Kerk by pogings tot opstand, burgeroorlog en rewolusie betrokke. Ons weet egter dat die oorweldigende meerderheid van die lidmate hulle nie in hierdie pogings gesteun het nie. Die feit dat die meerderheid lidmate van die Hervormde Kerk nie in 1994 vir radikale opsies vatbaar was nie, beteken nie noodwendig dat sake in die toekoms so sal bly, soos wat tans die geval is nie. Die politieke omstandighede kan maklik in 'n rigting ontwikkel waar die temas van minagting van die owerhede, opstand en rewolusie weer relevant kan word. Dit is daarom noodsaaklik dat die Hervormde Kerk 'n standpunt oor hierdie sake sal inneem. Dit is belangrik dat ons aan die lidmate van die kerk sal kan sê hoe die nagmaalsformulier vandag verstaan moet word. Dit is binne die konteks van 'n demokratiese regstaat nie meer so maklik om uit te maak wat 'sondige' miskenning en opstand teen die owerhede is nie, aangesien weerstand en opstand deel van die politieke proses binne 'n demokratiese regstaat is. Die vraag is: wat is vir die kerk en sy lidmate in die stryd om reg en geregtigheid geoorloof en by watter punt behoort 'n kerkraad 'n lidmaat toegang tot die nagmaal te weier?

\section{DIE NAGMAALSFORMULIER AS VERTREKPUNT VIR DIE KERKLIKE NADENKE.}

Kerklik kan 'n mens kwalik anders as om oor hierdie probleem aan die hand van die nagmaalsformulier te begin nadink nie. In die formulier het ons nie net met 'n teologiese mening te make nie, maar met ' $n$ bindende konsensus binne die Calvinisme. In hierdie teks word die gesagsondergrawing van owerhede en rewolusie teen die staat as sonde gesien. Wie volgens die formulier in hierdie sonde volhard, behoort toegang tot die nagmaal geweier te word. In die nagmaalsformulier word dit soos volg gestel:

Daarteenoor sal diegene wat nie hierdie gesindheid en voorneme by hulleself vind nie, die oordeel van God oor hulle bring as hulle aan die nagmaal deelneem. Daarom wil ons dan ook, in ooreenstemming met die bevel van Christus en die apostel Paulus, almal wat die volgende sondes doen, waarsku om nie aan die nagmaal van die Here deel te neem nie en aan hulle verkondig dat hulle buite die ryk van Christus verkeer. Ons praat van mense wat ... skeuring in die kerk en rewolusie teen die staat 
wil veroorsaak, almal wat meineed pleeg en almal wat die gesag van hulle ouers, meerderes en owerhede misken. Hierby ook alle moordenaars, bakleiers, rusiemakers en dié wat in haat en nyd teenoor hulle naaste lewe.

\section{DIE BEDOELING VAN EN DIE PROBLEEM MET DIE NAGMAALS- FORMULIER.}

Die formulier is aan die kerkorde van die Pfalts (Nov 1563) ontleen. Die feit dat die formulier oorspronklik ' $n$ kerkordelike raamwerk en konteks gehad het, sê klaar vir ons dat ons hier met 'n aspek van die dissipline, opsig en tug van die kerk te make het. Die nagmaal van die Hervormde Kerk (vgl Van't Spijker 1980:366, 371) is in hierdie opsig nie 'n oop maaltyd nie (vgl Koekemoer 1992:815-825 vir 'n teenargument). Lidmate besit nie 'n onvervreembare reg van toelating tot die nagmaal nie. Die toelating tot die ontvangs van die nagmaal, hang van 'n voorwaarde af. Die voorwaarde is dat lidmate deur hulle lewenswandel te kenne gee dat hulle God vir hulle verlossing dankbaar is. In die Christelike lewenswandel is daar sekere dinge wat gedoen en sekere dinge wat nagelaat moet word. Van die dinge wat 'n Christen moet nalaat om vir toelating tot die nagmaal te kwalifiseer, is onder andere opstand, rusie, twis, haat en nyd. Die formulier stel dit selfs-dat diegene wat in hierdie sondes volhard, buite die ryk van God is en die oordeel van God oor hulle self bring. Die nagmaalsformulier dwing kerkrade daarom om met lidmate en ampsdraers wat by opstand en rewolusie betrokke is, onder die opsig en tug te handel.

Die nagmaalsformulier skep die indruk dat daar sonder enige uitsondering van 'n gelowige gehoorsaamheid en onderdanigheid verwag word. Die vraag is of só 'n interpretasie van die vyfde gebod met die geheel van die Bybelse en Reformatoriese teologie versoenbaar is? 'n Verdere vraag is of só 'n standpunt vandag binne 'n demokratiese regstaat probleemloos gehandhaaf kan word?

\section{DIE BYBELS-REFORMATORIESE TEOLOGIE TOT EN MET DIE NAG- MAALSFORMULIER.}

Dit word vandag algemeen aanvaar dat die Bybelskrywers, vroeg-kerklike teoloë en die Reformatore in geen onduidelike taal die aspek van gehoorsaamheid en onderdanigheid aan die owerhede beklemtoon het. Dit word aanvaar dat hulle van gelowiges verwag het om slegs onreg te verduur en te duld, sonder om self iets ter verandering van die omstandighede te mag doen. Dít is egter nie die volle verhaal nie. 


\subsection{Paulus en die Christenmartelare.}

Paulus se Romeine 13:1-7 is wel ten diepste 'n lojaliteitsverklaring aan die owerheid. Hierdie Skrifdeel is ook geen geïsoleerde uitspraak ten opsigte van hierdie saak nie. Nie net 1 Pet 2:13-17; Tit 3:1 en 1 Tim 2:1-2 dui op dieselfde houding nie, maar ook die drie weergawes oor die betaal van belasting (Mark 12:13-17 par) en die vier weergawes van die lydingsgeskiedenis van Christus ${ }^{1}$. Wat hierdie uitsprake van Paulus en die ander skrywers merkwaardiger maak, is die feit dat hulle eintlik 'n bose owerheid (die Romeinse owerheid) in gedagte het. Hulle standpunt is dat 'n onregverdige owerheid nog steeds God se dienaar is en daarom gehoorsaam moet word. Hulle maak nie 'n onderskeid tussen regverdige en onregverdige heerskappy nie. Alle owerhede, goed of sleg moet volgens hulle gehoorsaam word. Hierdie was (en is) 'n baie unieke standpunt. In die antieke staatsfilosofie was so 'n standpunt 'n onmoontlikheid. Die filosowe, byvoorbeeld Dio Chrysostomus (kyk Schottroff 1984:35-36 vir volledigheid) het duidelik tussen goeie en slegte owerhede onderskei, met die bedoeling dat die slegte owerhede nie die guns van die gode of die mense verdien nie.

Die Christendom moes in die Nuwe-Testamentiese tyd (en daarna) konflikte met die owerheid oorleef wat nie toevallige randverskynsels was nie, maar noodwendige gevolge van die Christelike geloof en moraal. Die probleem waarmee die Christene geworstel het, was veel omvattender as maar net die vraag na die hantering van onreg en geweld. Die eintlike probleem was: hoe hanteer jy 'n situasie waarin jy uitgedaag word om jou diepste godsdienstige oortuigings te verloën? Hulle het dus nie net met 'n etiese vraagstelling nie, maar ook met 'n godsdienstige vraagstelling geworstel. Nie net gehoorsaamheid aan die tweede tafel van die dekaloog nie, maar ook gehoorsaamheid aan die eerste tafel het die uitdaging uitgemaak. Die historiese werklikheid was dat Christene uitgedaag was om die grens van verdraagsaamheid te oorskry. Die Romeinse keisers het teenoor die onderworpe volke 'n politiek van integrasie gevolg. Hierdie integrasie het ten doel gehad om elemente van die Romeinse godsdiens met die godsdiens van die plaaslike bevolking te integreer met die uiteindelike bedoeling dat die 'nuwe godsdiens' die Romeinse mag en gesag godsdienstig sal legitimeer. Hierdie politiek móés vir die Christene probleme oplewer. Hulle sou bereid wees om die keiser te eer, maar beslis nie om hom te aanbid en te vergoddelik nie. Nie die Romeinse gode nie en ook nie die keiser nie, maar die Vader van Jesus Christus alleen mag aanbid word.

Paulus en die ander kerkleiers (kyk bv 1 Pet 2:12-13 en Tit 3:1-8) het in 'n situasie van uiterste provokasie nie mense tot opstand aangehits nie. Hulle het 'n ander weg gevolg. Hulle het volgehou dat die owerhede wat ter sprake is, selfs geëer moet word. Volgens Schelkle (1953:227) was Rom 13 standaardtoerusting vir die martelaars- 
apologie. Hy verwys onder andere na Policarpus wat konsekwent daarop gewys het, dat Christene geen ander keuse het as om in situasies van lyding en vervolging, nie net die owerhede te gehoorsaam nie, maar hulle selfs te eer. Hierdie respektering en verering van die owerhede is as goeie werke gesien. Op hierdie wyse het hulle die gelowiges aangespoor om die bose deur goeie werke te oorwin ${ }^{2}$. Dat hierdie argument deurslaggewend was, blyk uit die feit dat die teoloë van die $2 \mathrm{e}$ eeu dit in hulle apologie gebruik het. Hier kan byvoorbeeld verwys word na Teofilus, biskop van Antiogië wat in sy geskrif aan Autolycus III, 14 van hierdie argument gebruik gemaak het. Ook uit die martelare-aktes is dit baie duidelik dat die Christene selfs onder marteling onderdanig gebly het en voortgegaan het om die bose te oorwin deur die goeie te doen. In die martelare-akte van die Christene van Scilië (180 n C) word berig dat Speratus die volgende aan die prokonsul van Afrika gesê het: 'Ons het nooit bose dade gepleeg nie, [ons] het onder geen wyse ongeregtigheid bewerk nie; ons het nooit gevloek nie, maar eerder gedank wanneer ons sleg behandel is; daarom bewys ons eer aan ons keiser' (my vertaling van Wlosok 1970:43).

Ten spyte daarvan dat daar geen ruimte vir weerstand gebied is nie, is daar egter wel ingesien dat die Christene 'n bepaalde etiese opdrag het. Die forensiese situasie van die vervolgde Christene ${ }^{3}$ was volgens Schottroff (1984:19) nie net 'n toets vir hulle gehoorsaamheid aan die owerhede en aan die opdrag om die bose deur die doen van die goeie te oorwin nie, maar ook aan die gebod oor die liefde vir die vyand wat neerkom op die opdrag om van alle weerwraak afstand te doen. Voor die stadsregeerder Perennis het Apollonius ( \pm 185 n C) gesê:

Jesus het ons geleer om die toorn te bedwing, die begeerlikheid te onderdruk, die lus te beteuel, die swaarmoedigheid te ban, verdraaglik te wees, die liefde te vermeerder, die ydelheid te los, jou nie met wraak teen beledigers op sleeptou te laat neem nie, nie die dood(straf) op grond van 'n hofuitspraak te minag nie, nie omdat 'n mens onreg gedoen het nie, maar omdat jy dit in geduld verdra; verder om al sy ander wette te gehoorsaam, die keiser te eer, maar God, wat alleen onsterflik is, te aanbid.

(Rauschen 1913:325; my vertaling)

In 'n situasie waarin mense weens hulle geloofsgehoorsaamheid vervolg en gedood is, het Paulus konsekwent aan die etiese voorskrifte van Jesus vasgehou. Aan die hand van Jesus se etiek moes die Christene hulle angswekkende lewenssituasie hanteer. 
Hierdie etiek kom op die volgende neer: Moenie kwaad met kwaad vergeld nie (Rom 12:17) en moenie self wraak neem nie (Rom 12:19). Hierdie uitsprake van Paulus gaan duidelik na Jesus se woorde van 'moenie die bose weerstaan nie' (Matt 5:38-48) en sy wegwysende optrede onder provokasie (Matt 26:47-56) terug. Die drie voorbeelde wat Jesus noem rondom die opdrag om van vergelding af te sien, sal volgens Schottroff (1984:25-26) in die praktiese uitlewing daarvan op gerigsprofetiese handelinge neerkom. Mense moet dus van vergelding afsien, met die bedoeling dat hulle met hierdie optrede aan hulle vyande sal kan verkondig dat God hulle vir hulle onreg sal straf. Om van geweld af te sien beteken dus om vir God se gerigshandelinge ruimte te skep. Die Christene se gehoorsaamheid op etiese gebied het dus vir hulle hoop op politieke gebied ingehou. Die martelare het hulle ook met die gerig van God getroos. Irenaeus (Iren Adv Haer V,24) wat op grond van Spreuke 8:15 selfs die heerskappy van tiranne na God toe teruggevoer het, het juis daarom die volgende gesê: 'die staatsinstansies wat die indumentum justitiae/die klere van die reg aan het, se gesag word nie bevraagteken nie en hulle quaecum que juste et legetime fecerint/wat regverdig en op 'n wettige wyse handel, sal ook nie bestraf word nie. Dié wat egter ad eversionem justi, inique et impie contra legem, et more tyrannico/tot omverwerping van die reg, op 'n onregverdige wyse teen die wet en soos tiranne optree, moet aan die straf van God oorgelaat word, want hulle sal nie die gerig van God kan ontvlug nie. Die aanvaiarding dat 'n onregverdige owerheid nog steeds God se dienaar is, het nie by die Christene tot vertwyfeling gelei nie, maar eerder tot hoop. Hulle het geweet dat só 'n owerheid ook in die hand van God is en bly en dat die mag van die bose maghebbers spoedig tot 'n einde sal kom. God, die Regter, Hy aan wie die wraak toekom, sal deur sy gerig nie toelaat dat die onreg langdurig gedy nie. Hy maak 'n einde aan alle aardse onreg.

Boosdoeners word egter nie net met die gerig gedreig nie. Jy as mens moet ook jou verantwoordelikheid nakom, want God handel ook deur menslike optredes. Wat 'n Christen wel kan en moet doen, is om boosdoeners tot omkeer en bekering te bring. Dit is daarom nie snaaks dat die gebod oor die liefde vir die vyand (Matt 5:43-48) op die gebod oor die vergeldingsweerhouding volg nie. Die vyand moet nie net toegelaat word om te benadeel sonder om terug benadeel te word nie, maar hy moet ook deur die liefde en barmhartigheid oorweldig word, sodat hy tot omkeer sal kom. Vyandsliefde beteken dus nie om 'n ander toe te laat om kwaad te doen nie, maar om hom tot kind van God te verander. Hierdie opdrag, en die bedoeling daarvan, het Jesus self in Getsemane uitgelewe (Matt 26:47-56). Hy self het van vergelding afgesien om daardeur aan sy vyande die oordeel van God te verkondig en om hulle met sy liefde te oorweldig, sodat hulle hulle sal bekeer om sodoende nie slagoffers van God se gerig te word nie. Presies dít het Paulus dan ook in Rom 12:14-21 geleer. Die implikasie van 
dit alles is dat ' $n$ mens nie van totale pasifisme of ' $n$ selektiewe pasifisme by die eerste Christene kan praat nie (kyk Heyns 1988:186-191). Alhoewel protes en weerstand nie vir hulle opsies was nie, het hulle tóg ingesien dat 'n Christen nie net onreg moet duld en ly nie (dít natuurlik ook), maar ook aktief, in kreatiewe liefde, moet meewerk om dit te verhoed en te verander.

\subsection{Die Reformatore.}

Martin Luther het by Paulus aangesluit en gelowiges tot absolute gehoorsaamheid aan die owerhede opgeroep. Luther het hom aanvanklik baie skerp teen opstand uitgelaat. Hy het tot en met 1529 daarop gestaan dat 'n Christen homself net tot die Woord en die gebed mag wend wanneer hy onderdruk word. Hy wou selfs nie eers die die teorie van die tirannemoord ${ }^{4}$ ondersteun nie. Die een belangrike rede waarom opstand (selfs teen 'n tiran) nie vir hom 'n opsie was nie, is die gevaar van anargie. Luther het eenmaal geskryf:

Dit is beter dat 'n tiran julle honderdmaal onreg aandoen as wat julle ' $n$ tiran eenmaal onreg aandoen. Wanneer daar onreg gely moet word, is dit verkiesliker dat die onderdane en nie die tiran hierdie onreg sal ly nie, omdat die gepeupel geen perke het en ken nie en omdat daar in elkeen van hulle vyf tiranne is. Dit is daarom beter om van een tiran, die owerheid, as van ontelbaar veel tiranne, die gepeupel, onreg te ly.

$$
\text { (WA 19,635 = 1991:62; my vertaling) }
$$

Calvyn het Luther se argument rondom die anargie ondersteun. Ook hy het tirannie bó anargie verkies. Calvyn ([1559] 1992:1833 = Inst IV, 20, 10, 78-80) het op voetspoor van Dio Cassius toegegee dat dit sleg is om onder iemand te lewe by wie niks toelaatbaar is nie, maar dit uitgewys dat dit baie slegter is om onder iemand te lewe by wie alles toelaatbaar is.

Die unieke van Calvyn se standpunt is dat hy nie net oor staatsgehoorsaamheid in 'n negatiewe sin gepraat het nie. Gehoorsaamheid was vir hom ook 'n baie positiewe en kreatiewe aangeleentheid. Gehoorsaamheid kom vir hom onder andere ook neer op die betaal van belasting, die opneem van openbare take en verantwoordelikhede (op grond van Tit 3:1) om daardeur die algemene welvaart te beskerm en te bevorder. Hy beklemtoon veral die openbare welvaart waartoe elke burger moet bydra as wyse van gehoorsaamheid (Calvyn [1559] 1992:1849 = IV, 20, 23, 27-31). Barmhartigheidswerk, sosiale opheffingswerk, ontwikkelingsprogramme is dus volgens Calvyn wesen- 
like take van 'n owerheid. Tot hierdie taak moet die burgers bydra deur nie net met anargistiese bedrywighede ontwrigting te veroorsaak nie, maar om self ook tot hierdie programme 'n positiewe bydrae te lewer.

Verset teen die owerhede is volgens Calvyn totaal onaanvaarbaar aangesien verset teen die owerheid op verset teen God neerkom (Calvyn 1992:1849 = IV, 20, 23, 23). As daar iets in die staatsbeleid is wat reggestel moet word, moet daar nie met oproer gereageer word nie, maar moet hierdie sake deur dialoog en onderhandeling opgeklaar word (Calvyn 1992:1849 = IV, 20, 23, 31-36). In die geval van 'n tirannie (leef in wellus, is net bedag op eie belange, verkwansel alle regte, voorregte, vonnisse en begenadigingsbriewe, tap arm mense, pleeg geweld, verkrag vroue, pleeg moord en roof), waar geen spoor van die beeld van God meer waarneembaar is nie (Calvyn 1992:1850 = IV, 20, 24), bly die reël dieselfde: jy moet die owerheid gehoorsaam wees. Calvyn sê:

\begin{abstract}
Maar as ons ons oë na die Woord van God wend, lei dit ons verder, naamlik dat ons ons nie alleen aan die gesag van vorste moet onderwerp wat hulle taak teenoor ons behoorlik ... uitvoer nie, maar ook aan die gesag van almal wat op enige manier regeer - al sou hulle glad nie doen wat die plig van vorste van hulle vereis het nie .... Verder dat diegene wat tot voordeel van die publiek regeer, ware voorbeelde en bewyse van sy goedgunstigheid is, maar dat diegene wat onregverdig en swak regeer, deur Hom verwek is om die ongeregtighede van 'n volk te straf, maar dat hulle almal met daardie majesteit beklee is waarmee $\mathrm{Hy}$ die wettige mag toegerus het.
\end{abstract}

$($ Calvyn 1992:1851 = IV , 20, 25, 1-14)

Calvyn bring ook hier ' $n$ ongewilde perspektief in die debat na vore. Hy meen dat selfs 'n tirannieke owerheid gehoorsaam moet word, aangesien só 'n owerheid God se owerheid is waarmee Hy mense wil straf. As bewys daarvoor dat 'n goddelose koning die Here se toorn oor 'n land is (Calvyn 1992:1850 = IV, 20, 25, 17), verwys hy na Job 34:30; Hosea 13:11; Jesaja 3:4; 10:5; Deut 28:29. Calvyn (1992:1852 = IV, 20, 26, 6-7) herinner ons aan die woorde van Daniël 2:21, 37 waar daar geskrywe staan: 'die Here verander die tye en die wisseling van tye; Hy sit konings af en Hy stel konings aan'. Verder vermaan hy almal op grond van 1 Samuel 8:11-17 (Calvyn 1992:1852 = IV, 20, 26, 28-46) en Jeremia 27:5-8.17 (Calvyn 1992:1853 = IV, 20, 27) om hierdie nuwe (onaanvaarbare) owerhede te gehoorsaam aangesien hulle daar is 
weens God se voorsienigheid en wil. Calvyn (1992:1853 = IV, 20, 27, 17-20) sê: 'As ons voortdurend in gedagte en voor oë hou dat selfs die slegste konings volgens dieselfde besluit van God aangestel word as waarmee die gesag van alle konings bepaal word, sal opruiende gedagtes nooit by ons opkom nie.' Calvyn (1992:1855 = IV, 20, 29, 25-31) sê verder: 'As ons daarom wreed deur 'n wrede vors getreiter word ... as ons laastens deur 'n goddelose en heiligskennende vors wanweë ons godsvrug geteister word, moet ons eerstens oor ons eie oortredings nadink omdat dit ongetwyfeld met sulke gésels deur die Here getugtig word. Na aanleiding hiervan sal ootmoedigheid ons onverdraagsaamheid beteuel'. Dit beteken egter nie dat Calvyn mense wat onder tirannie leef, sonder hoop in die lewe laat met die enigste verwagting om maar net te ly nie. Hy bied wel aan mense hoop, maar dan hoop wat in God self gegrond is. Die hoop waarmee 'n gelowige in tye van onderdrukking en tirannie leef, is die hoop wat op die oordeel en gerig van God wag. Calvyn (1992:1856 = IV, 20, 30) wys daarop dat God op sy tyd 'n onregverdige owerheid sal onttroon en met 'n ander owerheid sal vervang. As begronding vir sy standpunt verwys hy na Moses, Otniël, die Egiptenare, die Assiriërs en die Chaldeërs wat deur die Here gebruik is om bose oorheersing en onderdrukking te beëindig. Calvyn beklemtoon dit egter dat mense (die onderdruktes) nie self regter moet speel nie. Calvyn (1992:1857 = IV, 20, 31, 8-12) sê: 'As die wraak van die Here immers daarin bestaan om teuellose oorheersing te bestraf, moet ons nie daarom dadelik dink dat die bestrawwing ons toevertrou is nie. Aan ons is slegs die gebod gegee om die owerheid te gehoorsaam en te verdra'.

Die vraag is of Calvyn nou regtig van gelowiges verwag het om hulle voorbehoudloos en grensloos aan elke owerheid te onderwerp? Die antwoord is 'n duidelike néé. Calvyn dui, op grond van Paulus en die vroeë kerklike tradisie, 'n duidelike grens vir die gehoorsaamheid en onderdanigheid van die volk aan die owerheid aan. Hierdie grens is die wil van God. Calvyn sê:

... ons moet veral daarop let dat so 'n gehoorsaamheid (soos hierbo bespreek) ons nie wegneem van die gehoorsaamheid aan God nie. Die begeertes van alle konings moet trouens aan sy wil ondergeskik wees; al hulle bevele moet voor sy besluite swig en hulle septers moet aan sy majesteit ondergeskik wees. Hoe verkeerd sou dit inderdaad nie wees dat jy, om mense tevrede te stel, God se toorn verwek om wie se ontwil jy juis aan mense gehoorsaam is nie? .... Aangesien die gebod dat ons God eerder as mense moet gehoorsaam, deur 'n hemelse boodskapper, naamlik Petrus, afgekondig is, moet ons ons met die gedagte vertroos 
dat ons eers dan die gehoorsaamheid wat die Here van ons eis, betoon wanneer ons liewer enigiets ly as om van ons godsvrug af te wyk.

(Calvyn 1992:1858 = IV, 20, 32, 1-46)

Indien dit aanvaar word dat Calvyn hier 'n grens vir gehoorsaamheid stel, en dat hy sê dat 'n owerheid nie in alles gevolg en geduld hoef te word nie, is die vraag of hy en die ander Reformatore die burgers teen omstandighede wou beskerm, waar weerstand 'n noodwendigheid was? Het hulle enigsins vir die regte van die burgers opgekom? Het hulle ingesien dat daar ' $n$ etiese verantwoordelikheid bestaan om mense teen onreg te beskerm? Die antwoord is ' $n$ duidelike ja. Calvyn het die reg en geregtigheid van die burgers deur die regspraktisyns laat beskerm. Sekere volksamptenare/volksmagistrate/Volksbehorden (magistratus populares) het volgens Calvyn wel die plig en verantwoordelikheid gehad om die owerheid se mag te kontroleer en aan bande te lê. Daarvoor kon hy hom op 'n lang tradisie beroep. Calvyn verwys na die ephori wat teen die Spartaanse koning aangestel is, die volkstribunes teen die Romeinse konsuls en die distrikshoofde teen die senaat van die Atheners (Calvyn 1992:1857 = IV, 20, 31, 15-18). Calvyn beklemtoon dit dat die volksverteenwoordigers (wat van tyd tot tyd en van plek tot plek in gestalte mag verskil) wel die dure plig het om die magsuitoefening van die owerheid te kontroleer en aan bande te lê, indien dit op magsmisbruik sou uitloop. Hulle mót die vryheid van die volk beskerm (Calvyn 1992:1857 = IV, 20, 31, 25-27). Calvyn het dus wel die beginsel aanvaar dat die burgers deur die reg ${ }^{5}$ teen die magsmisbruik van heersers beskerm moet word.

Alreeds teen 1526 het Luther ook besef dat die dinge nie so eenvoudig soos in sy aanvanklike standpunt was nie. Hy het besef dat owerhede nie onbegrensd kan doen wat hulle wil nie. In die nog onverloste wêreld is daar altyd die moontlikheid dat mense met mekaar in botsing en selfs gewelddadige botsing kan kom. Luther noem in sy geskrif van 1526 Ob Kriegsleute auch in seligem Stande sein können/Of soldate ook die saligheid kan beërwe drie moontlike gewapende konflikte tussen mense:

a. twee persone van gelyke regte,

b. 'n belangrike teen 'n onbelangriker persoon,

c. 'n onbelangrike met 'n belangrike persoon.

In die gevalle a en $\mathrm{b}$ is wapengeweld altyd 'n moontlikheid en dikwels selfs 'n noodsaaklikheid. Konings kan teen mekaar oorlog maak en 'n koning mag dit nodig vind om met wapengeweld teen onderdane op te tree. Wapengeweld in geval $c$ is egter nie 
toelaatbaar nie, aangesien dit met Romeine 13 in stryd sal wees. Ten spyte van sy sterk afkeer aan opstand teen die owerheid, het Luther ingesien dat dit nodig is om een grensgeval uit te sonder waar geweld teen ' $n$ meerdere wel toelaatbaar is. Dit is in die geval van ' $n$ waansinnige heerser, want dan het jy nie meer met 'n mens te make nie, aangesien hy nie verstandelik tot die doen van die regte en die goeie in staat is nie. Geweld teen ' $n$ waansinnige heerser beteken ook nie noodwendig dat hy doodgemaak moet word nie. Die verkieslike is dat hy onttroon moet word en in gevangeskap aangehou moet word (Luther 1991:61 = WA 19, 634).

Ná 1529 het Luther nog meer genuanseerd begin argumenteer en met ander insigte na die tiranne en weerstand teen die tiranne begin kyk. Hy het drie kategorieë tiranne onderskei. In die geval van die tyrannus ex parte officii - die ampsmisbruiker - mag daar slegs passiewe weerstand uitgeoefen word. In die geval van die tyrannus ex defectu tituli - die usurpator - mag die magistrate aktiewe weerstand uitoefen. In die geval van die apokaliptiese tiran - hy wat sy magswil as die enigste bron van die reg laat geld - mag daar onbegrensde weerstand wees (kyk Wolf 1975:308-309 vir verwysings). Hierdie mening van Luther, dat 'n apokaliptiese tiran uit noodweer beveg mag word, het 'n belangrike wending in die sosiaal-etiese teorievorming teweeggebring. Volgens hom is absolute gehoorsaamheid aan alle owerhede, lyding en gebed nie meer die enigste wat teologies oor hierdie sake gesê kan word nie. Die mens kan volgens hom self op grond van sy rede en gewete besluit om onmenslike owerhede te keer en selfs met geweld te keer wanneer hulle hulleself aan onmenslike optrede skuldig maak.

Op grond van hierdie ontdekking waartoe Luther gekom het, het hy begin om weerstandsaksies teen die keiser te ondersteun. Om daarom te beweer (soos so dikwels in die verlede die geval was) dat Luther en die vroeë Lutherane slegs op onvoorwaardelike gehoorsaamheid en onderdanigheid aan die owerhede (selfs tiranieke owerhede) klem gelê het, is dus nie waar nie (kyk Douma 1984:193-197). Luther het na die ryksdag te Augsburg (1530) vir die reg van verset teen keiser Karel V gekies. Te Schmalkalden het die Lutherse vorste en stede dan 'n verdedigingsbond gesluit. Alhoewel hierdie verbond verdedigend van aard was, het dit tog beteken dat die Lutherane vasbeslote was om hulle self teen die keiser te verset indien hy sou aanval. Verder is daar ook van ' $n$ juridiese argument (menseregte argument) gebruik gemaak. Daar is gestel dat die keiser teenoor die keurvorste 'n verpligting het, aangesien hulle hom gekies het en hy by sy kroning 'n eed afgelê het waarin hy sekere verpligtinge en sekere beperkinge van sy mag aanvaar het. Sou hy hom nie by hierdie ooreenkomste hou nie, sou die vorste die reg hê om hulle gehoorsaamheid op te sê. Laastens het die Lutherane ook met 'n privaatregtelike teorie hulle dreigende opstand teen die keiser 
geregverdig. Die Lutherse juriste het een aspek van die kanonieke reg na die politiek deurgetrek. Hulle argument was dat dit geoorloof is om teen 'n onregverdige regter in verset te kom. In hierdie geval mag geweld met geweld gekeer word (vim vi repellere licet). Die keiser is as die hoofregter gesien wat sy mag misbruik en om daardie rede mag sy geweld met geweld gekeer word.

In 1550, dertien jaar voor die kerkorde van die Pfalts tot stand gekom het, het die Lutherse predikante van Maagdeburg 'n belydenisskrif (Confessio et apologia pastorum et reliquorum ministrorum ecclesiae magdeburgiensis, opgestel deur Nikolaus von Amsdorf) die lig laat sien waarin die reg tot gewapende verset erken word. Hierin is daar van die konstitusionele teorie gebruik gemaak wat 'n laer magistraat 'n goddelike opdrag gee om 'n hoër magistraat te weerstaan wanneer hy sy onderdane vervolg. Konkreet het dit beteken dat 'n stad soos Maagdeburg, deur sy laer magistrate, sy onderdanigheid aan keiser Karel V kon opskort wanneer hy tiraniek begin optree.

Samevatting: Calvyn verwag, in lyn met Paulus en Luther, absolute gehoorsaamheid aan die owerhede. Selfs 'n tirannieke owerheid moet geduld word, aangesien so 'n owerheid God se straf oor die sondes van die verlede is. Nogtans erken Calvyn die reg tot verset. Hierdie voorreg geld nie vir die bevolking nie, maar vir persone wat regtens daartoe geroep is. Wat wel van die bevolking verwag word, is om ongehoorsaamheid aan alles wat met die wil van God in stryd is, te openbaar. Luther het aanvanklik, op grond van eksegetiese insigte alleen, op 'n konsekwente gehoorsaamheid aan alle owerhede aangedring. Hy en sy volgelinge het tot die insig gekom dat fundamentalisme nie alle probleme kan oplos nie. Om hierdie rede het hulle verskillende staatkundige en regsteorieë in die teologiese debat ingevoer om hulle in 'n posisie te plaas om brandende sosiale, politieke en kerklike probleme op te los.

\subsection{Die Gereformeerde belydenisskrifte.}

Die Gereformeerde belydenisskrifte het basies dieselfde standpunte as die Reformatore gehuldig. Hulle het almal konsekwent op die onvoorwaardelike gehoorsaamheid aan die owerhede aangedring. Nogtans is daar reg deur die bank ingesien dat die gehoorsaamheidsplig 'n grens het. Daar kan omstandighede ontstaan waar daar nie van 'n Christen gehoorsaamheid verwag kan word nie. Hierdie omstandighede ontstaan beslis nie deur die ongelowigheid of onchristelikheid van die owerhede nie. Die Confessio Gallicana (kyk Rohls 1987:304) stel dit duidelik na aanleiding van Handelinge 4:17 dat 'n Christen die owerhede moet gehoorsaam solank God se opperheerskappy (l'Empire souverain de Dieu) ongeskonde bly. God se heerskappy word egter nie deur die ongelowigheid van amptenare geskend nie. Ook aan heidense owerhede moet die nodige eer bewys word en ook aan hulle moet belasting betaal word (Matt 17:24). In die West- 
minster Confession (Rohls 1987:304) word weer gesê: 'Infidelity or difference in religion does not make void the magistrates just and legal authority, nor free the people from their due obedience to him: from which ecclesiastical persons are not exempted'. Die reg tot ongehoorsaamheid word volgens die belydenisskrifte tot die anti-goddelikheid van wette en die totale versaking van hulle plig om vir reg en vrede (Confessio Helvetica posterior) te sorg, beperk. Slegs wanneer wette met die wil van God in stryd is en daar ' $n$ algehele situasie van wanorde en ongeregtigheid heers, mag gehoorsaamheid geweier word. Gehoorsaamheid mag in so 'n geval geweier word, aangesien daar aanvaar kan word dat 'n owerheid wat wette maak wat met die Dekaloog in stryd is en geensins meer in vrede en geregtigheid belangstel nie, 'n tirannieke owerheid is.

Ongehoorsaamheid aan 'n tirannieke owerheid kan verskillende vorms aanneem. In die Geneefse Belydenis word gepraat van (geweldloos) weerstand bied (résister) en in die Hongaarse Belydenis word van burgerlike ongehoorsaamheid gepraat. Hierdie terme word uitdruklik gebruik omdat dit vir die opstellers slegs om ongehoorsaamheid (non parere) en nie om gewelddadige weerstand gaan nie (kyk Rohls 1987:305).

Binne die Calvinisme is daar egter een uitsondering waar daar tog verder gegaan word. Die Skotte het in hulle Confessio Scotica, Artikel 14 gesê dat die gehoorsaamheid van die gebod 'jy mag nie doodslaan nie' onder andere beteken dat jy tirannie moet onderdruk (tyrannidem opprimere). Hierdie opdrag sien die Skotte as deel van die naasteliefde wat daarop neerkom dat die lewens van onskuldiges beskerm word, tirannie onderdruk en die onderdruktes bygestaan word. Weerstand teen politieke magsmisbruik, selfs met geweld, val dus vir die Skotte binne die raamwerk van die verantwoordelikheid vir die beskerming van lewe. Die unieke van die Skotse posisie is dat dit nie net 'n weerstandsreg nie, maar ook 'n weerstandsplig verkondig het. Wat nie uit die teks self duidelik blyk nie, is wie vir hierdie weerstandsaksie verantwoordelik is: die bevolking of ' $n$ bepaalde instansie? Teen die agtergrond van die Calvinistiese denktradisie moet ' $n$ mens aanvaar dat dit nie die bevolking self kan wees nie.

Dit behoort nou alreeds duidelik te wees dat die etiese oordeelsvorming nie eensydig op die onderdanigheid en gehoorsaamheid aan die owerhede klem kan lê nie, maar ook op die reg tot verset teen onmenslikheid. Nie net die dulding van onreg het 'n plek in die Christelike etiek nie, maar ook die verantwoordelikheid van die skepping van menswaardige lewensomstandighede.

\section{DIE TEOLOGIESE ONTWIKKELING NA DIE NAGMAALSFORMULIER VAN 1563.}

Dit moet aanvaar word dat die teologieë van Calvyn en Luther ' $n$ wesenlike rol by die opstel van die nagmaalsformulier gespeel het. Die standpunt van die nagmaals- 
formulier oor geweld, opstand en rewolusie kan sonder twyfel in die Reformatore se teologie teruggevind word. Die teologie het egter nie in 1563 tot 'n stilstand gekom nie. Geweldige teologiese veranderinge en aanpassings het na vore gekom, onder andere as gevolg van die veranderinge op politieke, staatkundige en regsgebiede. Dit is veral die beginsel van die reg tot verset wat in hierdie jare deeglik uitgewerk is. Om tot ' $n$ relevante interpretasie, uitleg en gebruik van die formulier te kom, sal mens van hierdie ontwikkelinge kennis moet neem.

'n Belangrike ontwikkeling wat in die teologie ná Luther en Calvyn plaasgevind het, was rondom die saak van die weerstand teen die tiran. Luther en Calvyn het die reg van weerstand teen 'n tiran deur die laer magistrate tot 'n vaste beginsel uitgewerk. Die reg van verset deur laer magistrate is wel eerste deur die Lutherane verkondig, maar dit is op die ou einde deur die Calviniste gepropageer. Hier moet veral na Theodor Beza (1519-1605), die opvolger van Calvyn verwys word. In sy geskrif $D u$ droit des Magistrats (oor die reg van die magistrate) het hy hierdie beginsel verdedig. Wat vir ons van belang is, is dat Beza as monargomag (tiran- of koningbevegter) aan Luther en Calvyn se oortuiging vasgehou het dat die bevolking, en veral individuele lede van die bevolking, nie die reg tot opstand het nie. Hierdie voorreg was net vir sekere verantwoordelike (regs)persone beskore. In hierdie opsig is Beza deur Francois Hotman en sy geskrif Franco Gallia ondersteun. In lyn met hierdie beginsel dat die volk nie die reg tot opstand het nie, het Beza 'n innovasie geskep. Hy het saam met ander teoloë ' $n$ belangrike geskrif wat Frederik van Pfalts, Johan van Nassau en Willem van Oranje tot verset teen die keiser aangespoor het, die lig laat sien. Saam met Du Plessis Mornay, Hotman en Languet het hulle 'n geskrif Vindiciae contra tyrannos onder die skuilnaam Brutus gepubliseer. In hierdie geskrif ontvang nie net meer die magistrate die reg om in opstand te kom nie, maar ook sekere volksleiers.

Die Nederlanders het ' $n$ verdere belangrike ontwikkeling in hierdie diskoers gebring. In 1566 het die Sinode van Antwerpen besluit dat daar met geweld teen 'n owerheid opgetree kan word wanneer mense van hulle godsdiensregte en godsdiensregte alleen ontneem word (Coertzen 1987:63). In 1581 het die Plakkaat van Verlatinge die lig gesien. In die inleidende paragraaf is daar die beroemde uitspraak gemaak dat die onderdane nie deur God geskape is ten behoewe van die vors nie, maar dat die vors ter wille van die onderdane geskape is sonder wie hy geen vors is nie (Douma 1984:200). Onder invloed van hierdie geskrif het die Nederlanders hulle teen Philips II verset. Die belangrike is dat hulle nie slegs weens die skending van hulle godsdiensvryheid teen Philips II in verset gekom het nie, maar ook weens die aanhoudende skending van hulle grondwetlik vasgelêgde regte. Hulle het hulle in hierdie dokument op sowel die konstitusionele teorie (dat die keiser en die vorste 'n 
ooreenkoms het waarby gehou moet word) as op die natuurreg (dat mens jou eie vryheid op die spel mag plaas ter wille van die bestryding van vorstelike tirannie) beroep.

Om hierdie ontwikkelinge te begryp is dit nodig om te besef dat Luther, Calvyn en die Hugenote (Coertzen 1987:61) se insigte dat die mag en outoriteit van die owerheid nie onbeperk soewerein kan wees nie, tot die insig van die volksoewereiniteit gegroei het. Dit was veral Althusius se Politica (1603) wat hierdie insig onder woorde gebring het. Hy het dit uitgewys dat die regerende heerser as die maiestas personalis aan die maiestas realis van die volk ondergeskik is. Dit kom daarop neer dat ' $\mathrm{n}$ regering op grond van ' $n$ sosiale verdrag die volk regeer en dat gehoorsaamheid aan die owerheid sal afhang van sy implimentering van die gemeenregtelike beginsels. 'n Regering regeer daarom ter wille van die welsyn van die mense. Om hierdie rede het die insig algaande ontwikkel dat die reg en nie die regering soewerein is nie en dat die pluralisme in die politiek as 'n beginsel aanvaar moet word, aldus: dat 'n demokratiese regstaat die allerbeste staatsvorm is.

\subsection{Menseregte}

'n Wesenlike uitvloeisel van 'n demokratiese regstaat is 'n handves van menseregte. In die Nederduitsch Hervormde Kerk was daar in die verlede groot wantroue en weerstand teen die gedagte van 'menseregte' (kyk bv na Wolmarans 1962; Mans 1973; Van der Westhuizen 1978). Hierdie weerstand het in 'n groot mate met die ideologiese stryd om apartheid te make gehad (König 1993:88-102). Ek is van oortuiging dat ons met nuwe oë na 'menseregte' 6 moet kyk. Ek gee toe dat daar talle probleme ${ }^{7}$ met 'menseregte' mag bestaan. Ek is egter daarvan oortuig dat die basiese idee van 'menseregte' 'n heilvolle idee is wat uit die eeue lange stryd tussen heerser en onderdane gegroei het en waaraan die Christelike teologie ${ }^{8}$, soos in die vorige hoofstuk beskryf, geen geringe aandeel gehad het nie. Hierdie idee verhinder 'n heerser of owerheid om willekeurig die regte van mense te skend. Wanneer 'menseregte' dus hier verdedig en gepropageer word, gaan dit bloot om die magspolitieke aspek - die aspek waardeur owerhede verbied word om deur magsmisbruik, burgers se basiese regte as mense te skend. Hierdie gedagte van menseregte het 'n eeue lange ontwikkeling deur gegaan.

Die diepste wortels van dít wat ons vandag onder menseregte verstaan, lê in die antieke Griekse filosofie. Die Stoa het alreeds besef dat daar 'n fundamentele gelykheid tussen alle mense bestaan. Daarom het hulle die onderskeiding tussen Grieke en (minderwaardige) barbare veroordeel, omdat Griek en barbaar albei redelike wesens is. Volgens hulle moes mense volgens hulle innerlike waarde en nie volgens hulle nasionaliteit en sosiale posisie beoordeel word nie. Chrysippus (kyk Douma 1990:34) het hieruit ' $n$ radikale konsekwensie getrek deur te verklaar dat die mens nie as stadsburger volgens stadswette gehanteer moet word nie, maar as wêreldburger volgens universele 
of algemeen geldige wette. Die Stoa het dus die beginsel neergelê dat alle mense menswaardig is en as sodanig behandel moet word. Geen regeerder mag dus met sekere mense maak wat hy wil, met die argument dat hulle minderwaardige mense is nie.

Hierdie aanvoeling dat alle mense menswaardig, regverdig en billik behandel moet word, is heel duidelik deur die Reformatore in hulle stryd teen die keiser opgeneem. Die ontwikkeling van die teologiese debat rondom die reg van verset, soos ons dit tot hiertoe beskryf het, loop parallel met die debat rondom die mens en sy regte teenoor die keiser. Al het die Reformatore en hulle opvolgers hulle nie met 'menseregte' as sodanig besig gehou nie, was hulle stryd teen die keiser niks anders as 'n stryd om 'menseregte' nie. Hy het volgens hulle nie die reg gehad om oor hulle lewens, denke en eiendom te beskik soos wat hy daarop aanspraak gemaak het nie.

Gaan 'n mens die politieke ontwikkeling van 'menseregte' na, dan blyk dit dat dieselfde grondpatroon hom voortdurend herhaal het. Mense, stede, volke wou dit doodgewoon nie toelaat dat iemand absolutisties hulle lewens beheer en vergal nie. Daar kan net na die volgende gevalle verwys word:

* Die Magna Charta Libertatum van 1215 was die grondslag van alle burgerlike vryhede in Engeland. Dit was die eerste oorwinning van die onderdane oor die koning. Vanaf 1215 was die koning alleen nie meer bevoorreg om belasting te vorder nie. Hy kon mense nie meer willekeurig in hegtenis neem of mense van hulle besittings beroof nie. Hy moes in ooreenstemming met die wette optree en handel. Vyf en twintig baronne is ook aangestel om die onreg van die koning te herstel, indien hy mense se regte sou skend. Op hierdie wyse is die reg van opstand gelegitimeer (Douma 1990:36). Ook buite Engeland kom 'n mens soortgelyke ooreenkomste tee. In die Brabant ontstaan daar in 1356 die Vryheidsregte van Joyeuse Entrée, in Duitsland in 1514 die Tübinger Vertrag van die stande met hertog Ulrich van Württemberg wat die heersersmag beperk en die positiewe reg beskerm. Die Unie van Utrecht 1579 het weer op grond van die katastrofale konsekwensies van die dertigjarige oorlog (1618-1648), die owerheid verbied om mense weens hulle godsdienstige oortuigings te vervolg. Daar is tot die besef gekom dat owerhede toleransie teenoor alle konfessionele groeperings moet openbaar. Die Edik van Nantes van 1598 is nog 'n voorbeeld van die begrip vir toleransie. Die Hollandse regsgeleerde Hugo Grotius het in hierdie verband ook die beroemde uitspraak gemaak dat daar 'n algemeen menslike reg oor alle godsdienste en konfessies moet bestaan (etsi deus non daretur), sodat godsdienstige mense op grond van regsbeginsels verhoed kan word om mekaar dood te maak. 
Die Habeas Corpus Act van 1679 beskerm weer die Engelse burgers teen willekeurige aanhouding. Daar is bepaal dat ' $n$ burger vir nie langer as 20 dae sonder verhoor aangehou kon word nie.

Tot en met die $17 \mathrm{e}$ eeu het ons nog met die voorstadiums van 'menseregte' te make. Tot hier gaan dit eintlik nog net om die bevordering van groepsregte: die adel teenoor hulle vors, die stede teenoor die adel, die kerk teenoor die adel. Alhoewel die gedagte van godsdienstige toleransie ontwikkel het, het dit nog nie op gelyke regte vir minderhede neergekom nie. Vanaf die 17e eeu, die tyd van die 'Verligting', is die gedagte gevestig dat vryheid nie van 'n bepaalde status afhang nie, maar elkeen se reg is. Rousseau en Lock het van die gedagte uitgegaan dat alle mense op grond van hulle natuurlike toestand gelyk is. Geen mens het daarom die reg om oor ' $n$ ander te heers nie. Gesag is wel noodsaaklik, maar dit word altyd volgens afspraak of 'n kontrak bepaal. Gesag berus dus by die volk en die volk alleen. Hierdie gedagtes, met die klem op die individuele regte, het dan ook neerslag gevind in die Amerikaanse Declaration of Independence van 1776 en die Franse Déclaration des droits de l' homme et du citoyen van 1789 . In hierdie verklarings is die mag van die staat beperk om aan elke individu alle ontplooiïnsmoontlikhede te gee. Thomas Jefferson het tydens die Amerikaanse onafhanklikheidsverklaring op 4 Julie 1776 gesê: 'Ons hou dit vir 'n waarheid wat geen bewys nodig het nie, dat alle mense voor hulle skepper gelyk is; dat Hy aan hulle bepaalde innerlike regte gegee het en dat tot hierdie regte lewe, vryheid en die strewe na geluk behoort'. Waar dit vir die Amerikaners hoofsaaklik om 'n naturregtelike saak gegaan het, het dit vir die Franse weer gegaan om die vernietiging van die Ancien Régime, die absolutistiese koninkryk. Vir die Franse was 'menseregte' dus gemik teen die magsaansprake van die koning en die adel. Hulle het nie die reg gehad om die bevolking te onderdruk, bloot omdat hulle adel en die ander gewone mense was nie. Die staat kry dus hier 'n bewakersfunksie. Hy moet toesien dat elkeen se vryheid, in die mate wat dit nie ander se vryheid bedreig nie, beskerm word.

Al hierdie ontwikkelinge op die gebied van 'menseregte' was die voorstadiums vir die ontwikkeling van die demokratiese regstaat waarmee gesê word: 'alle gezag moeten we respecteren maar we moeten geen enkel gezag verabsoluteren' (Douma 1984:199). Ons kan dus vandag nog kwalik argumenteer dat alle onreg wat deur die owerheid gepleeg word, eenvoudig geduld moet word. Vandag sal ons naas die Bybelse beginsel van gehoorsaamheid aan die owerhede, ook klem moet lê op die noodsaaklikheid van die skep en uitbouing van omstandighede wat gehoorsaamheid moontlik sal maak en geweld onnodig sal maak. 


\section{DIE DEMOKRATIESE REGSTAAT AS DIE INSTRUMENT IN DIE BEVOR- DERING VAN REG EN GEREGTIGHEID EN VERHINDERING VAN GEWELDDADIGE OPSTAND.}

Min mense (dit het die algemene verkiesing van 1994 in Suid-Afrika weereens bewys) het 'n passie vir geweld, anargie en burgeroorlog. Dit is een rede waarom alles in werking gestel moet word om hierdie aaklighede te voorkom. 'n Ander rede is dat die vernietigings-potensiaal van moderne wapens só groot geword het, dat lande oorlogsvoering binne sy eie grense ten alle koste moet voorkom. Alreeds in 1939 het Brunner (1939:455-461) daarop gewys dat die potensiaal om groot massas mense te vernietig, ou etiese teorieë soos die gedagte van 'n 'regverdige oorlog' (kyk by Hertz 1982 vir volledigheid) ongeldig gemaak het. Dit is duidelik vanuit die teologiegeskiedenis dat die grootste aanleiding vir gewelddadige opstand magsmisbruik deur 'n ongewensde maghebber was. Ek is van mening dat ' $n$ demokratiese regstaat die noodsaak vir gewelddadige opstand, rewolusie en tirannemoorde (minstens teoreties) bemoeilik en selfs verhinder, aangesien hierdie staatsbestel die booshede van die verlede (soos 'n apokaliptiese owerheid) eintlik onmoontlik maak. Om hierdie rede het die kerk en sy lidmate die verantwoordelikheid om die demokratiese regstaatlikheid te bestendig en te verdedig. In aansluiting by my vorige studiestuk (Van Wyk 1991:724731) kan die volgende redes vir hierdie standpunt aangevoer word:

\subsection{Die demokrasie.}

* Die demokrasie stel die burgers in staat om ongewensde persone uit 'n magsposisie te hou. Die mag van die regeerders is daarom legitieme mag.

* Binne ' $n$ demokrasie is mag verleende mag. Heersers kan hulleself nie as regeerders aanstel nie. Hulle word verkies.

* In 'n demokrasie word die regeerder(s) gevra om binne die raamwerk van 'n ooreenkoms of sosiale kontrak (partybeleid of verkiesingsbeloftes) wat deur die meerderheid goedgekeur word, te regeer. Die veronderstelling is dus dat die regeerder die wil van die burgers tot uitvoering sal bring.

* Magsuitoefening binne 'n demokrasie is tydelik van aard. Gereelde verkiesings wat gehou moet word, verhinder onbegrensde magsuitoefening.

\subsection{Die regstaat.}

* In 'n regstaat is die grondwet, en nie 'n koning of kabinet nie, die hoogste gesag. Willekeurige magsbesluite word só aan bande gelê. Mense het op hierdie basis minstens die teoretiese versekering dat hulle deur die owerhede menslik en menswaardig behandel sal word. 
* 'n Handves van menseregte of fundamentele regte, vorm deel van die grondwet van 'n regstaat.

* Die konstitusionele hof kontroleer die magsuitoefening van die parlement, regering en party.

* Die georganiseerde regswese (instellings soos die balierade en prokureursverenigings) behoort hulle soos in die dae van Calvyn en die volksmagistrate (populares magistratus), aktief vir reg en geregtigheid van die volk te beywer.

Suid-Afrika maak daarop aanspraak dat hy tans 'n demokratiese regstaat is. Die implikasie hiervan is, dat daar teoreties geen rede vir opstand en rewolusie is nie. Veral kerklidmate behoort hulle daarom aan die uitsprake van die Bybel en die nagmaalformulier, sonder enige gewetenskwellinge, te onderwerp.

\section{7. 'N MISLUKTE DEMOKRATIESE REgSTAAT AS HERNUDE AANLEI- DING VIR STRYD EN UITDAGING TOT OPSTAND.}

Die blote feitelikheid van 'n demokratiese regstaat is nog geen waarborg vir vrede, reg en geregtigheid nie. Dít hang ook van die funksionering van hierdie staatsbestel af. Soos in enige ander staatsbestel kan daar sukses behaal word of chaos kan ontstaan. Chaos kan een of ander tyd ontstaan, aangesien daar binne 'n demokratiese regstaat net soveel onreg, onregverdighede, ongeregtighede, korrupsie en magsmisbruik kan voorkom as binne enige ander staatsbestel. In ons geval is dit ook nie uitgesluit dat die sonde tóg uiteindelik weer die oorhand sal kry nie. Selfliefde ${ }^{9}$ in die gestaltes van groepsbevoordeling en haat in die vorm van groepsbenadeling kan maklik die algemene interesse van 'n demokratiese regering word. Die sonde kan dan daartoe aanleiding gee dat die hele gedagte van demokratiese regstaatlikheid bedreig word. Die volgende bedreigings kan genoem word:

\subsection{Die bedreigings vir die demokrasie}

* Weerhouding van verkiesings uit vrees vir magsverlies.

* Die doelbewuste uitskakeling van belangrike minderheidsgroepe uit besluitnemingsprosesse om op hierdie wyse diktatories op te tree.

\subsection{Die bedreigings vir die regstaat}

* Die gevaar bestaan altyd dat maghebbers nie volgens die eise van reg en geregtigheid sal regeer nie. 
* Die reg kan vertrap word wanneer die handves van menseregte geskend word. Dit kan op verskillende maniere gebeur:

- die vertrapping van die handves van menseregte deur die maghebbers;

- die aanstelling van regters met politieke belange;

- intimidasie van die konstitusionele hof;

- oneerlikheid/ideologiese blindheid van die regters van die konstitusionele hof;

- 'n uitleg van sekere artikels van die handves van menseregte wat weer tot omgekeerde diskriminasie aanleiding kan gee soos byvoorbeeld die saak van regstellende aksie;

- die onbereidwilligheid van staats- en semi-staatsinstellings om binne die gees van die handves te werk ten opsigte van byvoorbeeld die taalbeleid;

- wanneer daar 'n stagnasie van regsontwikkeling intree.

\section{DIE VERANTWOORDELIKHEID EN REGMATIGE OPTREDE VAN DIE CHRISTEN IN SITUASIES VAN ONREG BINNE DIE DEMOKRATIESE REGSTAAT.}

Daar is alreeds daarop gewys dat Calvyn byvoorbeeld besef het dat gehoorsaamheid aan. owerhede ook moontlik gemaak en moontlik gehou moet word. Gehoorsaamheid aan Romeine 13 beteken dus ook om gehoorsaamheid juis moontlik te maak. Vanuit die teologiegeskiedenis blyk dit dat dit onwenslik is om net op die gehoorsaamheid aan die owerhede, die lyding van onreg en die gebed klem te lê. Daar moet ook op die mens en sy etiese verantwoordelikhede klem gelê word. 'n Mens kan hierdie teologiese grondbeslissing ook aan die hand van die Bergrede illustreer. Jy kan in die uitleg van die Bergrede byvoorbeeld nie net op die vergeldingsverbod (Matt 5:38-42) klem lê nie. Jy moet ook na die etiese opdrag tot die maak van vrede (Matt 5:9) verwys. En ons weet mos dat die maak van vrede hand aan hand met die skep van geregtigheid gaan (Ps 85:10). Kuitert (1985:135) is daarom reg as hy sê dat 'n ongekwalifiseerde gehoorsaamheid aan die vergeldingsgebod op onetiese optrede neerkom, omdat jy mense aan monsters kan uitlewer. Hierdie etiese denke kom ook in die Heidelbergse Kategismus voor. In die uitleg van die sesde gebod (antwoord 107) word die verbod van moord ook in 'n positiewe sin uitgelê, naamlik dat 'n mens verplig is om alles wat mense kan benadeel, te probeer verhinder. Op. geen wyse word hier gepleit vir ongehoorsaamheid aan byvoorbeeld Romeine 13 nie, maar slegs vir die insig dat gehoorsaamheid hieraan nie die etiese verantwoordelikheid uitsluit om juis gehoorsaamheid moontlik te maak nie. Ek gaan dus van die veronderstelling uit dat 'n Christen, of 
iemand anders ${ }^{10}$, nie verplig is om maar net onder alle omstandighede brutale onreg te bly verduur nie. Hy het ook die reg en verantwoordelikheid om verregaande onreg teen te gaan en te help verander. Dit is juis die Calviniste van die afgelope eeu (Barth 1957:538-648; Moltmann 1984:123-163) wat met behulp van die teorie van die koningsgsheerskappy van Christus ${ }^{11}$ daarop gewys het, dat sonder om die hemel op die aarde te bring, die kerk naas die verantwoordelikheid om die heil te verkondig, ook die verantwoordelikheid het om ten opsigte van die welwese 'n bydrae te lewer (Kreck 1975:336). 'n Ander faktor wat in gedagte gehou moet word, is die veranderde werklikheidservaring van die moderne mens. Die moderne mens ervaar die werklikheid nie meer as onveranderbare ontologiese gegewendhede nie, maar as veranderbare historiese moontlikhede. Die ordeningsdenke het só plek gemaak vir die historiese denke. Ook politieke ordeninge geld daarom nie meer as onaantasbare, ewiggeldende Goddelikhede nie, maar as veranderbare menslike prosesse (Moltmann 1974:146). Die implikasie is dat die kerk ook deel is van veranderingsprosesse en self 'n bydrae kan en moet lewer om veranderinge in ' $n$ bepaalde rigting te stuur. Teen die agtergrond van alles wat tot hiertoe gesê is, meen ek dat die volgende vir 'n Christen geoorloof is sonder dat die gees en bedoeling van die nagmaalsformulier in gedrang kom:

\subsection{Die aandrang op die herstel van die demokrasie}

* Die kerk en sy lidmate het nie 'n reg tot weerstand teen die demokrasie nie, maar slegs tot verdediging en herstel van die demokrasie (Kriele 1984).

* Die kerk en sy lidmate moet daarom op gereelde verkiesings aandring, aangesien dít die beste manier is om van onreg ontslae te raak en opstand te vermy.

* Die kerk en sy lidmate moet daarop aandring dat dit hulle demokratiese reg is om aan die prosesse wat na wetgewing lei, deel te neem.

* Die kerk en sy lidmate moet daarop aandring dat hulle afkeur oor wetgewing wat met die Woord in stryd is, die nodige gehoor vind.

* Die kerk en sy lidmate sal onregverdige owerhede met die feit moet konfronteer dat tirannie (ook die tirannie van die meerderheid) nie met die gedagte van 'demokrasie' in lyn is nie.

\subsection{Die aandrang op die herstel van die reg}

* Die kerk en sy lidmate moet in hulle profetiese getuienis daarop aandring dat die owerhede die grondwet sal respekteer en hulle daaraan sal onderwerp. 
* Daar moet daarop aangedring word dat die owerhede respek vir die handves van menseregte moet openbaar.

* Owerheidsoptrede wat met die handves van menseregte in stryd is, moet deur middel van die konstitusionele hof beveg word.

* Onetiese optrede deur (politieke regters van) die konstitusionele hof moet behulp van politici en instellings soos die 'regskommissie' beveg word.

* Die georganiseerde regswese behoort aangespreek te word, sodat hulle hulle beskermingsfunksie van die volk na behore sal nakom.

\subsection{Die aandrang deur middel van petisies, protesoptredes en wetlike stakings op} die hernude verbintenis tot geregtigheid.

* Onregverdige wetgewing het sy oorsprong in 'n gesindheid van ongeregtigheid.

* 'n Nuwe geregtigheidsgesindheid kan deur petisies, protesoptrede en stakings afgedwing word.

8.4 Geweldlose burgerlike ongehoorsaamheid (Douma 1984:176-203; Du Toit 1987; Heyns 1988:162-177) wat die volgende moontlikheid blootlê:

* Om in situasies waar ' $n$ owerheid nie meer in geregtigheid, maar slegs nog in selfhandhawing belangstel, sonder om wetsongehoorsaamheid aan te wakker, sonder om ander daartoe en daarmee te intimideer, sonder om die gesag van die owerheid te ondergrawe, en sonder om geweld aan te blaas, een enkele wet doelbewus en demonstratief deur ' $n$ massa mense wat mense sal insluit wat nie direk deur die onregverdige wetgewing geraak word nie, te laat oortree, met aanvaarding van die regskonsekwensies wat dit vir daardie mense mag inhou, sodat daar op hierdie wyse morele druk uitgeoefen kan word en gepleit kan word vir die beeïndiging van ' $n$ bepaalde onreg, deur die afskaffing van die spesifieke wet deur 'n owerheid wat homself vanaf 'n gesagsinstansie na 'n magsinstansie verander het ${ }^{12}$.

\subsection{Die vreedsane skep van stadstate of volkstate}

* Wanneer dit blyk dat daar selfs ná 'n gewelddadige opstand geen vooruitsig op reg en geregtigheid vir ' $n$ bepaalde groep mense sal wees nie, is afstigting ' $n$ moontlikheid wat oorweeg kan word.

* Wanneer dit blyk dat 'n mens hierdeur 'n groter kans het om konflik en geweld te vermy, kan selfs die kerk hierdie gedagte propageer. 
Die Christelike etiek laat dus groot ruimte vir deelname aan die politieke prosesse toe. Die Christen kan vandag met min gewetenswroegings aan aksies deelneem ter bevordering van reg en geregtigheid, sonder om as 'n opstandeling en revolusionêr gebrandmerk te word. Ten spyte hiervan is daar 'n grens, soos die nagmaalsformulier te kenne gee, wat 'n mens vandag nog nie mag oorsteek nie. Hierdie grens het vandag nog met gewelddadige verset te make.

\section{GEWELDDADIGE VERSET}

Die Gereformeerde belydenisskrifte en die Reformatoriese teologie tot in ons dekade (kyk Coertzen 1987:62-67; Heyns 1988:192-284; Van Wyk 1990; Heyns 1994; Kreck 1975:344-346; Smith 1988; Rendtorff 1981:167-171) bly daarby om geweld ten sterkste af te keur. Ten spyte daarvan dat ons weet dat daar tog wel omstandighede kan ontstaan, waar daar geen ander keuse is, as om geweld as 'n laaste opsie te gebruik nie ${ }^{13}$, kan geweld nooit deel wees van 'n Christen se daaglikse politieke stryd nie. In ons dag word die probleemstelling egter deur sekere faktore sterk bemoeilik. Ons weet byvoorbeeld dat geweld 'n wesenlike deel van talle samelewingstrukture uitmaak. Waar geinstitusionaliseerde (Heyns 1988:195-197) of strukturele geweld (Louw 1987:32) deel van 'n samelewingstruktuur word, is daar dikwels ook van (verstaanbare) teengeweld en veranderingsgeweld (Rendtorff 1978:47-64) sprake. Die gevolg is dat daar so ' $n$ groot kringloop van geweld en teengeweld bestaan, dat ' $n$ mens kwalik nog van regmatige en onregmatige geweld kan praat. Wat ons vraagstelling nóg meer problematies maak, is die feit dat 'rewolusie' ook nie meer as 'n eenduidig-sondige saak getipeer kan word nie. 'Rewolusie' is nie meer noodwendig 'n gewelddadige omverwerping van 'n spesifieke owerheid nie, maar kan ook die term wees waarmee 'n proses beskryf word waardeur 'n totale samelewingstruktuur verander word, sonder dat daar werklik 'n eenduidige teenstander en eindvisie is (Trillhaas 1970:486-493). Nie almal wat aan 'n 'rewolusie' deelneem, kwalifiseer noodwendig vir kerklike tug nie, aangesien sommige rewolusies op politieke, maatskaplike, ekonomiese, industriële en wetenskaplike terreine vooruitgang, opheffing en verbetering kan impliseer (kyk vir volledigheid Fetscher 1982). Die volgende behoort duidelik te wees: Net so min as wat 'n mens 'n 'ideologie van geweldloosheid' kan verdedig, kan 'n mens 'n 'ideologie van geweldverheerliking' goedpraat. Absoluut geweldloos sal die wêreld nie wees nie en kan hy nie wees nie, aangesien daar 'n oormaat aan boosheid danksy geweld bestaan en net weer deur geweld beëindig kan word. Teologies kan en mag 'n mens geweld egter nooit goedpraat nie - selfs nie eers ten behoewe van edele ideale soos in 'n stryd om groter geregtigheid nie ('n goeie voorbeeld hiervan is Villa-Vicencio 1990). Geweld mag nie mooi maskers' gegee word nie (Heyns 1994), aangesien geen masker 
hierdie aakligheid mooi kan maak nie. In die lig van die voorafgaande meen ek tog dat persone wat hulle aan die volgende skuldig maak, onder die kerklike opsig en tug aangespreek moet word:

* Alle vorme van destruktiewe geweld (Louw 1987:33) wat met pyn, leed, beskadiging, vernietiging, ongeregtigeid en haat saamhang soos:

- Moord (en ook die dreigemente met moord).

- Terrorisme (Heyns 1988:199-207; Rendtorff 1978:65-66) teen 'n demokratiese regstaat ten tye van relatiewe vrede en geregtigheid, aangesien hierdie simboliese geweld neerkom op die selfsugtige begeerte om jou wil ten alle koste, deur die skep van vrees, op ander af te dwing.

- Rewolusie (Heyns 1988:207-218) teen 'n wettig-gekose, internasionaal erkende regering deur ' $n$ groep uit die bevolking, wat poog om met geweld self die regering oor te neem, teen die wil van die meerderheid van die bevolking.

- Anargisme (Heyns 1988:218-222) wat deur romantici (die NGB, Art 36 praat van hulle as die Wederdopers en ander oproerige mense) veroorsaak word deurdat hulle 'n samelewingsbestel probeer afdwing waarin hulle die staat as instelling wil laat verdwyn deur die samelewing op grond van spontane regsverhoudinge te probeer organiseer, met die konsekwensie dat die burgers van hulle beskerming ontneem word.

Kerkrade sal egter baie versigtig moet oordeel. Daar kan 'n situasie ontstaan waar geweld verstaanbaar en selfs noodsaaklik kan raak. Só 'n situasie kan ontstaan wanneer:

* Christene gedwing word, om wette wat met die wil van God in stryd is, te gehoorsaam. Hierdie dwang moet die vorm aanneem van langdurige intimidasie, benadeling en gewelddadige behandeling;

* daar 'n langdurige en totale vertrapping van fundamentele menseregte plaasvind;

* daar langdurige selektiewe benadeling voorkom;

* daar ná langdurige gesprekke en pogings tot gesprekke deur die betrokkenes, hulporganisasies soos Amnesty International, buitelandse regerings en ander bemiddelaars, die owerheid nie tot billikheid en menslikheid beweeg kan word nie; 
* die afsien van geweld aanleiding tot groter euwels sal gee as wat deur 'n weerstandstryd veroorsaak sal kan word (Wilckens 1982:43);

* die voorstanders van die gewelddadige weerstandsaksie 'n alternatiewe grondwet en regering gereed het;

* 'n waarborg gegee kan word dat daar nie 'n lang uitgerekte burgeroorlog sal ontstaan nie;

* 'n waarborg gegee kan word dat daar nie sprake gaan wees van gyselaars, marteling en moord op gevangenis nie - (kyk veral na Lorenz 1984: 11-12, 24-35 vir groter volledigheid).

Enige burger en weerstandsgroepie kan ook nie in só ' $n$ situasie oor geweld besluit nie, maar volgens Reformatoriese tradisie alleen die volgende volksverteenwoordigers: parlamentslede, regters, generaals van die veiligheidsdienste en (my byvoeging) kommissies van kerklike sinodes. Ek sluit predikante en teoloë doelbewus by hierdie groep in. Weens die oorweldigende afkeur van geweld deur die Bybel en die Reformatore, het die kerk die taak om ook in só ' $n$ belangrike besluitnemingsproses, sy profetiese roeping na te kom. Die kerk behoort enduit die gewete van die volk te bly. Ten tye van sulke kritiese besluitnemingsprosesse sal die kerk se verteenwoordigers nie anders kan as om die gelowiges daarop te wys, dat ons weg 'n weg van lyding, geduld, verduring van God se gerig oor die 'onlangse sondes van die volk' (Calvyn), vyandsliefde, voorbidding vir die owerhede en vertroue op God en sy gerig is nie.

\section{KONKLUSIE}

Uit die ondersoek blyk die volgende:

- die nagmaalsformulier moet onverkort en onveranderd gelaat en gehoorsaam word;

- daar is vir ' $n$ Christen nog steeds geen regverdiging om aan gewelddadige verset deel te neem nie;

- geweldlose verset en opstand is vir 'n Christen nie alleenlik 'n opsie nie, maar kan binne sekere omstandighede 'n plig word;

- die kerk sal in sy hantering van die nagmaalsformulier 'n duidelike onderskeid moet tref tussen legitieme geweldlose weerstand teen onreg en onaanvaarbare gewelddadige verset en lidmate wat hulle aanhoudend aan laasgenoemde skuldig maak, sal derhalwe van die nagmaal uitgesluit moet word; 
- in 'n situasie van langdurige fundamentele onreg teen lidmate, behoort die kerk en sy opsigliggame daarvoor begrip te hê dat lidmate vir 'n kort tydjie ${ }^{14}$ by geweld teen 'n bose owerheid betrokke kan raak;

- die kerk behoort dit by lidmate in te prent dat geweld 'n allerlaaste opsie is en daarom moet die kerk in sy opsigtaak seker maak dat alle moontlike geweldlose aksies tot die uiterste beproef is;

- die kerk moet enduit die hoop verkondig dat Christus as die Heer van die wêreld, deur sy gerig vir reg en geregtigheid sal sorg;

- die kerk het die taak om die gewetens van sy lidmate op te skerp en om in voorbidding vir die owerhede te volhard, sodat ons 'n rustige en stil lewe kan lei (1 Tim 2:2).

\section{ENDNOTAS}

1 Die lydingsgeskiedenis van Jesus was onder andere ' $n$ demonstrasie van weerhouding van verset teen die staatsmag.

2 Hierdie argument berus op die volgende eksegetiese basis: die beroemde teorie van Ernst Käsemann (1974:337-347) dat Rom 13 'n 'Fremdkörper' is, word verwerp. Schottroff (1984:1618) en De Villiers (1987:34-45) het oortuigend aangedui dat Rom 13:1 'n voortsetting van Rom 12:21 is. Volgens hulle bestaan daar daarom 'n saaklike samehang tussen 13:1-7 en 12:1-21. Beide gedeeltes is 'missionêre daadgetuies'. Rom 12:1-21 bevat die vredes-en liefdesgetuies van die gelowiges en 13:1-7 die missionêre daadgetuienis oor die gelowige se lewe in die politieke lewe van elke dag. Die twee hoofstukke vul mekaar dus aan. Die gehoorsaamheid aan die owerheid van hoofstuk 13 kan daarom nie beredeneer word sonder die etiek van hoofstuk 12 nie.

3 Met forensiese situasie word bedoel: die aanklag, verhoor, skuldigbevinding en marteling van die Christene. Teenoor hierdie tese sou gestel kan word dat Paulus en die ander Christene tydens die skryf van die Romeinebrief nog nie vervolging ervaar het nie. Dit is egter nie waar nie. Christene is in hierdie tye al wel vervolg op grond van hulle konflikte met nie-Christene. Selfs Paulus was al in konflik met die Romeinse owerhede -- vergelyk bv 2 Kor 11:25 en Rom 8:35 (kyk Schottroff 1984:19 vir volledigheid).

4 Die Rooms-Katolieke Kerk het vir eeue lank aan die hand van die teorie van die 'tirannemoord' (Wolf 1975:304-307) en die teorie van die 'noodweer' (Kreck 1975:327-330) gewelddadige weerstand geregverdig. 
5 By Calvyn gaan dit nog om sekere regspersoonlikhede wat die burgers moet beskerm. Hierdie gedagte sou in ons dag ontwikkel tot die beskerming deur ' $n$ handves van menseregte.

6 Ek meen dat Douma (1990:34) se definisie van menseregte 'n aanvaarbare definisie is: 'Onder mensenrechten verstaat men die elementaire rechten, die onmisbaar worden geacht voor de politieke en sociale ontplooiing van de mens, en die om universele erkenning vragen'.

7 Teologies bestaan daar heelwat probleme rondom 'menseregte' soos die legitimasie van menseregte, die identifikasie van dít wat 'n mensereg is en nie noodwendig is nie, die botsings tussen verskillende 'regte' en die probleem om menseregte te laat realiseer (kyk Douma 1990:3945).

8 Dit kan nie ontken word dat die Christelike kerk en teologie 'n wesenlike bydrae tot die ontstaan en ontwikkeling van menseregte gelewer het nie. Dít is in die vorige hoofstuk bewys. Al sou daar ook geen tekste uit die Bybel ter ondersteuning van 'menseregte' aangehaal kan word nie, bestaan daar wye instemming dat Bybelse temas soos skepping, versoening en verlossing wesenlik tot die ontwikkeling van 'menseregte' bygedra het (kyk Douma 1990: 46-49). Ook al sou 'n mens die tese moet verwerp dat 'menseregte' die (uitsluitlike) vrug van die Christelike evangelie is, sal 'n mens die tese, wat dikwels in ons kerkblaaie gepropageer is (kyk bv Gregan 1993), dat 'menseregte' Marxisties is, as verregaande moet verwerp.

9 Vanaf Augustinus tot by Pannenberg is sonde o a met behulp van die begrip 'selfliefde' omskryf (kyk vir 'n oorsig na Pannenberg 1983:83-116).

10 John Rawls (1972:371-377; 1975:136-137) wys ook daarop dat ten spyte daarvan dat burgers binne 'n konstitusionele demo-krasie verplig is om wette te gehoorsaam wat na hulle mening onregverdig is, hulle die reg het om met burgerlike ongehoorsaamheid op wette wat alle perke van duldbaarheid oorskry, te reageer.

11 In 'n vorige artikel (Van Wyk 1991:736-740) het ek 'n poging aangewend om 'n kombinasie te maak tussen die Lutherse twee-ryke-leer en die Calvinistiese koningsheerskappy-van-Christusteorie. Dáár het ek die klem op die Lutherse teorie laat val. In hierdie artikel hou ek by hierdie kombinasie, met die klem egter hierdie keer op die Calvinistiese teorie.

12 Die klassieke voorbeeld is die gedagte van die 'regverdige oorlog' wat niks anders as 'n etiese kompromis is nie - 'n kompromis tussen die weersin aan geweld en die noodwendigheid van geweld ter wille daarvan om groot ellende te keer (kyk hiervoor Hertz 1982; Van Wyk 1986:145151). 
13 Natuurlik sal almal besef dat mense se waarborge nooit absolute waarde kan hê nie. Die sonde sal mense altyd maar weer oorweldig. Nogtans meen ek dat dit goed sal wees om mense onder hierdie morele dwangmaatrëls voortdurend op te skerp met die bedoeling dat geweld eintlik 'n onmoontlike saak sal wees. Romeine 13 behoort altyd 'n meulsteen om die nek van gelowiges te bly.

14 Gewelddadige opstand moet die doelwit hê om binne 'n kort tydjie, met die minimum aan lewensverlies, met die versekering van sukses, die owerheid van standpunt te laat verander of omver te werp.

\section{Literatuurverwysings.}

Barth, K 1957. Die Kirchliche Dogmatik, III/4: Das tätige Leben, 538-648. Zürich: Zollikon.

Brunner, E 1939. Das Gebot und die Ordnungen: Entwurf einer protestantisch-theologischen Ethik. Zürich: Zwingli-Verlag.

Calvyn, J [1559] 1992. Institusie van die Christelike Godsdiens, Boek 4. Potchefstroom: CJBF.

Coertzen, P 1987. Burgerlike ongehoorsaamheid: 'n Kerkhistoriese perspektief, in Du Toit, D (samesteller), Staatsgesag en burgerlike ongehoorsaamheid. Kaapstad: Lux Verbi.

De Villiers, J L 1987. Die Christen en die staat volgens die Nuwe Testament, in Du Toit, D (samesteller), Staatsgesag en burgerlike ongehoorsaamheid, 54-69. Kaapstad: Lux Verbi.

Douma, J 1984. Politieke verantwoordelijkheid. Kampen: Van den Berg. (Ethische bezinning 13.)

1990. Ethiek en recht. Kampen: Van den Berg. (Ethische bezinning 15.)

Du Toit, D (samesteller) 1987. Staatsgesag en burgerlike ongehoorsaamheid. Kaapstad: Lux Verbi.

Fetscher, I 1982. Revolution und das 'Recht auf Revolution' in, Böckle, F u a (Hrsg) Christlicher Glaube in moderner Gesellschaft, 104-133. Teilband 14. Freiburg: Herder.

Gregan, S 1993. Is 'n handves van menseregte die antwoord? Die Hervormer 1 Junie, bl 5.

Heyns, J A 1988. Teolagiese etiek, Band 2/2. Pretoria: NG Kerkboekhandel.

Heyns, M F 1994. Maskers vir geweld. Potchefstroom: IRS. (Reeks F 1. No. 319.) Hertz, A 1982. Die Lehre vom 'gerechten Krieg' als ethischer Kompromiß, in Handbuch der christlichen Ethik Band 3, 425-448. Freiburg: Herder. 
Honecker, M 1978. Das Recht.des Menschen: Einführung in die evangelische Sozialethik. Gütersloh: Mohn. (GTB 290).

Irenaeus [1875]. Adversus Haeresus. Canterbury: Uitgawe W Harvey.

Käsemann, E 1974. An die Römer. 3. Aufl. Tübingen: Mohr. (HNT 8a.)

Koekemoer, J H 1992. Oop of geslote Nagmaalsviering? 'n Vraag aan die Nederduitsch Hervormde Kerk van Afrika. HTS 48, 815-825.

König, A 1993. Menslike mense: Gelowig nagedink, Deel 5. Halfway House: Orion.

Kreck, W 1975. Grundfragen christlicher Ethik. München: Kaiser.

Kriele, M 1984. Ein Recht auf Widerstand? Kritische Fragen eines Verfassungsrechtlers, in Lorenz, E (Hrsg) Widerstand, Recht und Frieden, 102-111. Erlangen: Martin Luther-Verlag.

Kuitert, H 1985. Alles is politiek maar politiek is niet alles: Een theologisch perspectief op geloof en politiek. Baarn: Ten Have.

Lorenz, E (Hrsg) 1984. Widerstand, Recht und Frieden: Kriterien legitimen Gewaltgebrauchs. Erlangen: Martin Luther-Verlag.

Louw, D J 1987. Versoening in geweld: 'n Pleidooi om vrede in Suider-Afrika. Kaapstad: NG Kerkuitgewers. (Stellenbosse Teologiese Studies 15.)

Luther, M [1526] 1991. Ob Kriegsleute auch in seligem Stande sein können [= WA 19], 623-662. Göttingen:Vandenhoeck. (Luther Deutsch. Bd 7. UTB 1656.)

Mans, C J 1973. Enkele kritiese opmerkings oor die teologiese grondslae van menseregte en 'n teologie van bevryding. HTS 29, 129-145.

Moltmann, J 1974. Rassismus und das Recht auf Widerstand, in Das Experiment Hoffnung. 145-163. München: Kaiser.

1984. Politische Theologie - Politische Ethik. München: Kaiser.

Nederduitsch Hervormde Kerk van Afrika. Besluite van die 63ste Algemene Kerkvergadering. Pretoria: Gutenberg.

Pannenberg, W 1983. Anthropologie in theologischer Perspektive. Göttingen: Vandenhoeck.

Rauschen, G 1913. Frühchristliche Apologeten und Märtyrerakten, Bd 2. München: Kaiser. (Bibliothek der Kirchenväter Bd 14.)

Rawls, J 1972. A theory of justice. Oxford: Oxford University Press.

1975. The justification of civil disobedience, in T L Beauchamp (ed), Ethics and public policy. Englewood Cliffs: Prentice-Hall.

Rendtorff, T 1978. Politische Ethik und Christentum: Möglichkeit und Unmöglichkeit christlicher Politik - Macht und Gewalt heute. München: Kaiser. (Theologische Existenz heute 200.) 
Rendtorff, T 1981. Ethik, Band II: Grundelemente, Methodologie und Konkretionen einer ethischen Theologie. Stuttgart: Kohlhammer.

Rohls, J 1987. Theologie reformierter Bekenntnisschriften. Göttingen: Vandenhoeck. - (UTB 1453.)

Schelkle, K H 1953. Staat und Kirche in der patristischen Auslegung von Rm 13,1-7. ZNW 44, 223-236.

Schottroff, L 1984. 'Gebt dem Kaiser, was dem Kaiser gehört, und Gott, was Gott gehört': Die theologische Antwort der urchristlichen Gemeinden auf ihre gesellschaftliche und politische Situation, in Moltmann, J (Hrsg), Annahme und Widerstand, 15-58. München: Kaiser.

Smith, D J 1988. Die verhouding tussen kerk en staat: Enkele modelle met verwysing na die reg van opstand teen die staat. HTS 44, 434-449.

Trillhaas, W 1970. Ethik. 3. Aufl. Berlin: De Gruyter.

Van der Westhuizen, H G 1978. Die Bybelse basis vir menseregte. HTS 34, 88-96.

Van'T Spijker, W 1980. Het klassieke avondmaalsformulier, in van't Spijker, W et al (red), Bij brood en beker: Leer en gebruik van het heiloig avondmaal in het Nieuwe Testament en in de geschiedenis van de westerse kerk, 363-419. Kampen: Goudriaan.

Van Wyk, I W C 1991. Protesoptogte en die rol van die Nederduitsch Hervormde Kerk. HTS 47, 716-745.

Van Wyk, J H 1986. Gesindheid en gestalte. Pretoria: NG Kerkboekhandel.

- 1990. Kerk, teologie en geweld, in Vensters op mag en geweld. Potchefstroom : IRS. (Reeks F3. Nommer 37.)

Wilckens, U 1982. Der Brief an die Römer. Röm 12-16. Neukirchen-Vluyn: Neukirchener. (EKK VI/3.)

Villa-Vicencio, C 1990. Civil disobedience and beyond: Law, resistance and religion in South Africa. Cape Town: David Philip.

Wlosok, A 1970. Rom und die Christen. Deutsche Übers. von Acta Scilitanorum 2 und 9. Stuttgart: Kreuz.

Wolf, E 1975. Sozialethik: Theologische Grundfragen. Göttingen: Vandenhoeck.

Wolmarans, H P 1962. Menswaardigheid en menslike regte na aanleiding van die Skrif. HTS 18, 83-90. 